\title{
Egiazko (in)dependentziez: energiaren ikuspegia Hego Euskal Herrian
}

\author{
Alain Ulazia \\ ILCLI eta IN eta Jariakinen Mekanika Saila (UPV/EHU) \\ Markel Penalba \\ Centre for Ocean Energy Research (Maynooth University)
}

\section{(On true (in)dependences: a view on energy in southern Basque Country)}

DOI: $10.1387 /$ gogoa.20368

\begin{abstract}
The present study intends to clarify the philosophical grounds of system energetics, ecosophy and sustainability, following the path introduced by Ulazia (2016) in a previous issue of Gogoa (Ulazia 2016), in order to establish the foundations of a pragmatic strategy for the energetic sovereignty of the Basque Country. First, avoiding excessive reductionism, we emphasize the importance of the problem of energy sovereignty for a real (in)dependence of a country, showing its relevance in the geopolitical sense. Using Lund's foundational research as analogy, the energy strategy of an independent Basque Country is suggested, taking into account the energy on the Danish situation consumption and generation data of Basque Autonomous Community and Upper Navarre. Currently, an important lack of renewable energy sources is observed in the current energy mix, which is a fundamental point in the sustainable development of a state. Hence, these empirical facts show that any discussion about independence is meaningless if the subject about the local and distributed implementation of renewable energies is not considered.
\end{abstract}

Keywords: energy, ecosofy, sustainability, sovereignty.

\section{Laburpena}

Lan honetan Gogoaren aurreko ale batean Ulaziak (2016) hasitako bideari jarraitzen diogu, sistema-energetikaren, ekosofiaren eta jasangarritasunaren oinarri 


\begin{abstract}
filosofikoak argitu eta gero, Euskal Herriaren burujabetza energetikorako estrategia pragmatiko baten fundamentuak ezartzeko. Erredukzionista izan nahi gabe, energiaren arazoaren garrantzia nabarmentzen dugu hasieran; izan ere, herri baten egiazko (in)dependentziari buruzko eztabaidan, oro har, aipatzen dena baino garrantzizkoagoa da energia, eta horren lekuko dira artikuluan aipatzen diren zenbait adibide geopolitiko. Danimarkako egoera eta Lunden lana erreferentzia gisara hartuta, Euskal Herrirako plan estrategiko baten oinarrien eta ereduen arteko konparaketa egingo dugu; horrela, EAEren eta Nafarroa Garaiaren egungo energiaren sorkuntza eta kontsumo-datuak aintzat hartuta. Energia berriztagarrien aparteko eskasia nabarmentzen da egin den ikerketan, eta horixe da, hain zuzen, herri baten garapena jasangarria dela esateko ezinbesteko baldintzetako bat. Beraz, emaitza enpirikook frogatzen dutenez, independentziari buruzko edozein debate hutsala da, debate horrek energia berriztagarrien inplementazio lokalaren eta bananduaren (deszentralizatuaren) gaia mahaigaineratzen ez badu.
\end{abstract}

Gako-hitzak: energia, ekosofia, jasangarritasuna, burujabetza.

\title{
1. Sarrera
}

Egungo merkatu intelektualean aldizkarietako artikuluen produkzio arranditsuarekin alderatuta, ahozko dialektikatik egindako 'eman ta zabal zazu' larrazabaldarra askoz efikazagoa delakoan gaude ikertzaileon memoria sortzailearentzat. Izan ere, ekosofia hitza, beste hitz esanguratsu asko bezala, Jesus Mari Larrazabali entzun zion egileetako batek lehenengo aldiz, une hartan eztabaidatzen ari ginen arazoa argitzera zetorren erreminta gisara mahaigainean ipini zuenean. Hitz gutxirekin asko esateko ahalmena, kontzeptu filosofikoen baitako ahalmen hori alegia, populu xehearentzako desagertzear/desagertaraztear dagoen erreminta politikoa dela esatea agian jada ez da gehiegi.

'Berdeen politikan' edo 'ekologia sakonaren mugimenduan' oinarrizkotzat jotzen den Arne Naess filosofoaren definizio aitzindariak honela definitzen du ekosofia:

Ekosofia esatean, harmonia eta oreka ekologikoaren filosofia esan nahi dut. Filosofia, sofia edo jakituria mota gisa, zabalki normatiboa da; normak, arauak, postulatuak, balioei buruzko lehentasun-ezarpenak eta hipotesiak dauzka bere baitan gure unibertsoaren egoerez. Jakituria jakituria politikoa da, preskripzioa, ez bakarrik deskribapen zientifikoa eta iragarpena. Ekosofiaren xehetasunek aldakuntza esanguratsu ugari erakutsiko dituzte, ez bakarrik poluzioaren, baliabideen, jendartearen eta abarren 'egitate'ei dagokienez, baita balioen lehentasunei dagokienez ere. ${ }^{1}$ (Drengson \& Inoue 1995: 8).

1 «By an ecosophy I mean a philosophy of ecological harmony or equilibrium. A philosophy as a kind of sofia (or) wisdom, is openly normative, it contains both norms, rules, postu- 
Beraz, ekosofiak, erreminta kontzeptual eta politiko gisa, naturari begirako giza balioen lehentasunaren arazoa jartzen du indarrean, oreka ekologikoaren baitan gizakiok hartzen dugun jokaeran. Ez da, beraz, aldaketa klimatikoaren inguruko estatistika eta balioespenetan oinarritzen den arazo ekologikoen deskribapen edo iragarpen zientifiko hutsa. Humanitateak eta zientziak aurrez aurre jartzen dituen funtsezko gai honen eta egungo instituzioen artean dagoen lubaki sakonean, zubi bat baino, eraikin berri bat behar da, teknologiaren neutraltasun ideologikoaren mitoa eraisteko eta gizakiaren natur balioen araberako beste zientzia bat garatzeko. Eraikin horrek estrategia sozialak eta politikoak determinatzen dituen teknozientzia moduko bat behar luke. Zeren, lubaki horrek eragin politiko zuzena dauka jendartea antolatzeko moduan, edo, hobeto esanda, naturaren deskribapenari eta iragarpenari buruzko ezjakintasun zientifikoaren kudeaketa politikoan. Lubakiaren tamainaren neurgailu bat izan liteke EAEko EIB (Energia Iturri Berriztagarriak) eta EII (Energia Itzulera Inbertitutakoarekiko) indize baxuak ${ }^{2}$.

Izan ere, energia ez da gizartearen antolakuntzaren eta kudeaketaren alderdi bat. Sistema-energetikak erakusten duenez, energiaren kontzeptuak ahalmen teoriko handiz axiomatiza lezake ikuspegi sozioekonomikoa, 'erregaibero-argindar-garraio' batasun kontzeptuala ezartzen baitu kontsumitzen ditugun baliabide naturalentzat (Ulazia 2016). Smilek (2008) erakusten duenez, energiaren kontzeptu batuaren edo sistemikoaren bidez aldaketa sozialak eta kulturalak ere eragin daitezkeela esatea ez da inondik inora erredukzionista. Geopolitikoki, baliabide energetikoei dagokienez dentsitate altuko gune espazialen menpekoa den gizarteak hierarkikoagoa izateko joera dauka, eta energia barreiatuagoa eta homogeneoagoa eskuragarri duen gizarteak, berriz, berdinzaleagoa. Honez gain, zibilizazioen desagerpena, erromatarrena adibidez, bere egitura politiko, ekonomiko eta militarrei eusteko behar zen energiaren (kasu honetan nagusiki zerealen produkzioa kilokaloriatan neurtua) eta egitura hauen bidez sortzen/kontsumitzen zuten energiaren arteko desorekaren emaitza gisa ere azal daiteke (Homer-Dixon 2007).

\footnotetext{
lates, value priority announcements and hypotheses concerning the state of affairs in our universe. Wisdom is policy wisdom, prescription, not only scientific description and prediction. The details of an ecosophy will show many variations due to significant differences concerning not only the 'facts' of pollution, resources, population, etc. but also value priorities.» (Drengson \& Inoue 1995: 8)

2 GOGOAren aurreko alean definitzen du egileotako batek EII sistema-energetikaren testuinguruan (Ulazia 2016). Energia-iturri batek inbertitutako energia-unitateko sortzen duen energia da; ratio adimentsional bat, beraz. Energia hidraulikoa da indize horren arabera iturri eraginkorrena eta haize-energiak petrolioaren EII-muga harrapatu du jada, petrolioaren energia-unitate bat lortzeko behar den energia handitzen ari baita, denborarekin putzu sakonagoak egin behar direlako eta eremu geografiko basatiagoetara jo behar delako (kontrol geopolitikoan gastatzen den energia guztia aintzat hartu gabe).
} 
Horrenbestez, energiaren kontzeptua erdigunera ekarri beharraz ohartuta, ezinbestekoa da subiranotasunaren (edo dependentziaren) eta energiaren arteko erlazio bereizezina azpimarratzea. Izan ere, herrien egiazko subiranotasuna edo, zergatik ez, 'erabakitze-ahalmena'ren maila (ikuspegi gradual bat onartu nahi bada, eta autarkian erori gabe), kanpoko herrialdeetako energiaren edo energia sortzeko baliabide naturalen beharraren araberakoa da; beste herrialdeekiko menpekotasun energetikoaren araberakoa, alegia. Menpekotasun horrek maila sozialean zein ekonomikoan eragin ukaezinezkoa du, are gehiago gaur egungoa bezalako mundu ezegonkorrean. Arrazonamendua muturrera eroanda, De Gaullek esan zuen bonba atomikorik ez daukan estatu bat ezin dela egiaz independentetzat eta subiranotzat jo; parekoa da bertako energia-iturriez esan daitekeena. Independentziari buruzko debate fundamentudun batean burujabetasun energetikoa ezin da, beraz, alde batera utzi.

\section{Energia eta geopolitika}

Baliabide naturalen/energetikoen garrantziaren erakusgarri dira (gasarena eta petrolioarena nagusiki, baina baita ibai emaritsuetako urarena ere) Bigarren Mundu Gerratik gaur arte munduak bizi izan eta bizi dituen gatazka militar nagusiak. Izan ere, zail da gatazka horiek ulertzen, alde baten (inbaditzailearen) baliabide-gosea eta bestearen (inbadituaren) baliabide-aberastasuna kontuan izan gabe.

Baliabide naturalak ahitzearen ondorioz, azken hamarkadetan energia faktore estrategiko giltzarria bihurtu den arren munduko potentzia handienentzat, baliabide energetikoen boterea lortzeko gatazkak ez dira inondik ere fenomeno berriak. APOC (Anglo-Persian Oil Company), gaur egungo BP (British Petrolium) multinazionalaren aitzindaria, izan zen lehena, 1909. urtean, Ekialde Hurbilean, petrolio-zundaketak egiten. Lurralde hartako baliabide naturalak ezagututa banatu zituzten Frantzia eta Erresuma Batuak Ekialde Hurbileko lurrak, Sykes-Picot akordioa gisa ezagutzen den hitzarmen ezkutuan (Havrelock 2016), bertako baliabideen kontrola heurenganatzeko.

Energia-baliabideen jazarpenak soilik azal dezake, aldi berean, Ameriketako Estatu Batuek (AEBek) duten Persiar golkoaren kontrolaren obsesio iraunkor bezain tragikoa. 90eko hamarkada hasierako Golkoko Gerrak (Aarts \& Renner 1991) irekitako bide beretik etorri ziren Afganistan (Monbiot 2001), Irak (Ahmed 2014) edo Siriako gerrak (Sayigh 2015), terrorismoaren eta demokraziaren izenean lurralde horietako baliabideak amerikarren kontrolpeko enpresen esku uzteko.

Munduko potentzia izateko energia-baliabideen garrantzia ondo barneratuta dauka Txinak ere, eta mundura irekitzeko duen planerako beharrezko dituen baliabideak lortzeko lanak aspaldi hasi ditu. Batetik, Hego Txinako 
itsasoaren jabe egin nahian ari da bizilagun dituen Filipinak, Vietnam edo Japonen gainetik. Izan ere, Hego Txinako itsasoan petrolio- zein gas-erreserba handiak egon daitezkeen susmoak areagotzen ari dira, eta itsasoaren inguruan bizi diren estatu guztiek ustiatu nahi dituzte erreserba horiek. Bestetik, hainbat akordio estrategiko sinatu ditu errusiarrekin 2013tik hasita, hurrengo hamarkadetan Errusiak petrolioa zein gasa prezio onean horni diezaion (Buckley 2016).

Errusia eta Europaren arteko azken urteetako liskarrak ere baliabide energetikoen kontrolean (besteak beste) oinarritutako gatazka baten ondorio dira, Krimearen anexioa kasurako (Orzaiz \& Unanue 2014). Kasu horretan ez dira zuzenean baliabide naturalak gatazkaren arrazoia, Ukraina edo Krimea ez baitira lurralde aberatsak gasean edo petrolioan, baizik eta baliabide horiek merkaturatzeko ohiko gasbideak: Ukraina Europar Batasunean sartzearekin batera, Europaren menpe geratuko liratekeen gasbideak, hain zuzen.

Izan ere, potentzia ekonomiko handien artean energia-menpekotasun handiena duen lurraldea da Europa, baliabide naturalen gabezia dela eta. Ondorioz, Europaren politika nazionalak zein internazionalak bere energiahornitzaile diren herrialdeen menpe geratzen dira. Europa mendebaldea Afrika iparraldeko gasaren menpe bizi da, Libiako gatazkan herrialde europarren jarrerak argi uzten duen gisan. Halaber, Europa ekialdeak, Alemaniak barne, errusiar gasarekiko erabateko menpekotasuna du, Krimeako anexioari oztoporik ez jartzeak erakusten duen bezala.

Antzerako egoerak aurki ditzakegu munduko kontinente guztietan; besteak beste, Argentina eta Britainia Handiaren arteko Malvinetako gatazka Hego Amerikan; Sudan eta Hegoaldeko Sudanen artekoa Afrikan; edo Errusia, Kanada, AEB, Norvegia, Finlandia, Suedia, Groenlandia eta Islandiaren artekoa Artikoan. Gatazka horiek guztiak arrazoi anitzetan oinarrituak egon litezke. Denek dute, hala ere, ezaugarri komun bat: energia-baliabideen kontrola. Izan ere, energiaren jabe izatea ezinbestekoa da potentzia ekonomikoen aberastasuna, boterea eta ospea mantentzeko (Klare 2012).

Inoren menpe ez bizitzeko era bakarra, beraz, norberak dituen baliabideak ustiatzea da. Petrolio- eta gas-erreserba handiak dituzten eta egonkortasun politikoa duten herrialdeetan - Saudi Arabian, Qatarren edo Arabiar Emirerri Batuetan, adibidez-, posible da erabateko energia-subiranotasuna. Badirudi AEBek ere erabateko energia-subiranotasuna bermatua dutela hurrengo hamarkadetarako, bere lurraldean aurkitutako arbel-gasaren erreserbak direla medio. Oso estatu gutxi dira, ordea, gaur egungo energia-sistema olioztatuan, subiranotasun hori berma dezaketenak, euren jarduera ekonomikoak drastikoki murriztu gabe.

Hori ulertzen lehenengo estatuetakoa izan zen Alemania. Alemaniak, errusiar gasarekiko duen menpekotasunetik ihesi nahian —erabiltzen duen gasaren \% 40 inguru dator Errusiatik (BGR 2014)—, bere baliabideak ustia- 
tzeko plana martxan jarri zuen; dituen baliabide berriztagarriak ustiatzeko plana, hain zuzen ere. Europan energia berriztagarrietarako jauzia eman dutenen artean daude Danimarka, Portugal, Eskozia eta Norvegia, adibidez, nahiz eta Eskozia eta Norvegiak gas- eta petrolio-erreserba handiak izan.

\section{Independentismoaren olatua}

Gatazkaz gatazka, munduaren egitura etengabe aldatzen joan da historian zehar. Gaur egun ezagutzen dugun mapa politikoa egitura horren bertsio modernoa da. Kasu gutxi batzuk salbu - Txinak 4000 urtetik gora daramatza, gorabeherak gorabehera, egungo lurralde-banaketa antzekoarekin-, gaur egun bost kontinenteetan ezagutzen ditugun herrialdeak azken mendeetan sortutakoak dira, gehienetan iraganeko erreinuen banaketa edo bateratze odoltsuetatik sortuak. Kolonizazio europarraren ondorengo kontinente amerikarrean, AEBetako (1776-1783) zein Hego eta Erdialdeko Amerikako independentzia-gerrek mapa politikoa hankaz gora jarri zuten XVIII. eta XIX. mendeetan. Afrikan zein Asian, etengabe azaleratzen dira inperio kolonialistek definitutako antolaketa berriaren gabeziak, eta etengabe lehertzen dira herritarren eta inperialisten lagun izaten jarraitzen duten agintarien arteko gatazkak. Ozeanian Australia da egun existitzen diren estatuen artean zaharrena, orain dela mende bat eskas sortutako estatua. Azkenik, Europaren antolaketa bereziki izan da ezegonkorra azken mendeetan, eta Bigarren Mundu Gerrak eta Jugoslavia eta SESBen erortzeak definitu dute gaur egungo Europako mapa politikoa. Noski, estatu-nazio modernoen etengabeko desagerpen eta sorrera honek ez du esan nahi iraganeko aroetan herrialdeek baliabideengatik eta energiagatik burujabetasun-borrokak izan ez zituztenik.

Afrikan eta Asian, non potentzia handien interesak alde batera utzi eta lurralde ezberdinetako ezaugarri etniko/kultural/sozialak kontuan hartuko dituen berregituraketa bat ezinbestekoa den, azken urteetako krisi ekonomikoek, politikoek eta sozialek agerian utzi dute mapa politikoa berregituratzeko beharra. Izan ere, krisi hauek agerian utzi dute egungo sitema politikoaren ahitzea, munduaren lurralde-egituraketa bera, nazio-estatuetan oinarria duena, zalantzan jartzeraino (Dasgupta 2018, Small 2006). Ondorioz, mugimendu independentisten olatu berri bat sortu da Europan. Mugimendu horien alderdi politiko-sozialaz luze eta sakon idatzi da azken urteetan. Gurean ere asko izan dira prentsa-artikuluetan, sare sozialetan, zein liburuetako orrietan estatu independente baterako bide-orriak aurkeztu dituztenak. Urriagoak izan dira, ordea, estatu independente horren komenigarritasunari edo bideragarritasunari buruzko eztabaidak eta lanak; salbuespen bat da Jurado 2010. Gure ustez, ezinbestekoa da independentziaren eztabaida fikziozko eremu sozio-politikotik atera eta errealitatera ekartzea, independentziak Euskal Herriko egitura ezberdinetan izango lukeen eragin erreala aztertzeko: ekonomian, industrian, ikerkuntzan, hezkuntzan edo kulturan, bes- 
teak beste. Izan ere, azken batean, «independentzia hobeto bizitzeko» delako argudioak (Apaolaza et al. 2016) oinarri sendoak eta fidagarriak behar ditu.

Lan honetan, balizko Euskal Herri independente baten biziraupenerako estrategikoa litzatekeen beste faktore garrantzitsu bat aztertzen da, orain arte, guk dakigunaren arabera, ia erabat ahaztu dena: energia. Hego Euskal Herriak subiranotasun energetikorako dauzkan aukerak, beharrak eta mugak aztertzen dira. Petrolio-putzurik, gas naturalik eta ikatz-erreserbarik ezean, bi aukera bakarrik gelditzen dira, benetako subiranotasun energetikoa lortzeko aukerarik bada: energia nuklearra eta energia berriztagarriak (Euskal Herrian haizea, eguzkia, olatuak, ibaietako ura eta biomasa).

Ez da hau energia nuklearraren debatea plazaratzeko lekua. Gainera, euren energia-sistema energia nuklearrean oinarritu zuten herrialdeak ere, Frantzia esaterako, nuklearretatik berriztagarrietarako jauzia emateko neurriak hartzen hasi dira. Ikatz-zentralak ere ixteko asmoa azaldu du Frantziak, besteak beste, eta 20 urtetan diesel- eta gasolina-autoak saltzea galarazteko asmoa ere adierazi du. Hori guztia energia berriztagarriekin ordezkatzeko erronka alimalekoa izan liteke, baina, iristen den punturaino iritsita ere, Europa mailan muga historiko bat ezarriko duela ematen du (Jacobsson 2009, Mikelarena 2017).

Energia nuklearra aparte lagata, energia berriztagarrien aukera da, gure ustez benetako independentziara iristeko bide bakarra, eta, beraz, horixe landuko dugu lan honetan. Alegia, ekosofiak eta sistema-energetikak ezartzen duten eredua; giza balioen, jendartearen, naturaren eta energia-sorkuntzaren arteko erlazioen jatorrian balio kolektiboak — hala nola jendartearen erabakitze-ahalmena, burujabetasuna eta garapen jasangarria- ezarriko dituen eredua. Kausa-ondorio erlazioak ez dira beti zuzenak; hau da, subiranotasun energetiko handiagoak ez du beti erabakitze-ahalmen handiagoa ekartzen, diktadura autarkiko batean, adibidez. Hala ere, zentro txikiak ugalduz energia-iturriak bertakotzeak, erabakiguneak ugaltzea eta kapitalaren banaketa berdintasunezkoagorako joera dakar, gaur egun boterea metatzen duten energia produzitzeko zentro handien (konpainia elektrikoen) kaltetan. Petrolio-putzuak edo uranio-meategiak botere handia pilatzen duten guneak dira, eta horien kontrol espazialak (militarrak eta geopolitikoak) are eta botere gehiago ematen dio okupatzaileari (fisikoki espazioa okupatzearen zentzuan). Energia-iturri demokratiko eta eskuragarriak denboran eta espazioan modu nahiko xumean baina uniformean barreiatzen diren energia-iturriak dira: eguzkia, haizea eta ura dira batez ere, eta zenbait lekutan olatuak, mareak eta biomasa ere bai. Izan ere, gure planetan uraren zikloaren barne-erregulazioaren bidez eguzki-energia toki guztietara hedatzen da, erradiazio moduan ez bada, euri moduan (energia potentziala pilatzen da), haize moduan (energia zinetikoa garatzen da), edo olatu moduan (energia zinetikoa zein potentziala aprobetxatzen da). 
Lan honetan erakutsi nahi dugu energia berriztagarrien aukera hau partziala ez ezik, integrala ere izan daitekeela; hori erakusten du Danimarkak azken urteetan izan duen eboluzioak. Danimarkak 5.5 milioi biztanle ditu eta hiritar danimarkarrari begira munduko gizarte-politika aurreratuenetakoa du. Ondorioz, toki askotan erreferentziatzat hartzen da, eta 90eko hamarkadatik hona berriztagarrien aldeko energia-politika argi eta progresiboa garatu $\mathrm{du}$, batez ere haize-energian oinarritua. \% 100 berriztagarria den energia-sistema helburu duen plan bat izan dugu oinarri konparaketa egiteko, energiaeredu alternatibo bati buruz eztabaidatzeko orduan kanonikotzat hartu ohi den lan bat; Lunden lana (Lund 2007), hain zuzen.

\section{Danimarkaren iraganeko egoera}

Lundek (2007), orain hamar urte argitaratutako lanean, Danimarkako energia-egoera aztertzen du, eta EIBen potentzial minimo zein maximoa 2003ko kontsumo-datuekin alderatzen du (ikus 1. irudia). Esan behar da potentzial maximoa azpitik zenbatetsi zutela, garai hartan ez baitzen itsasoko haize-energiak izan duen adinako garapena izango zuen aurreikuspenik. Gas naturala, ikatza eta petrolioa kontuan hartuta, taulan adierazten den energia-kontsumo totala (beroa, elektrizitatea eta garraioarentzako erregaia) EIBen bidez ase daitekeela ikusten da.

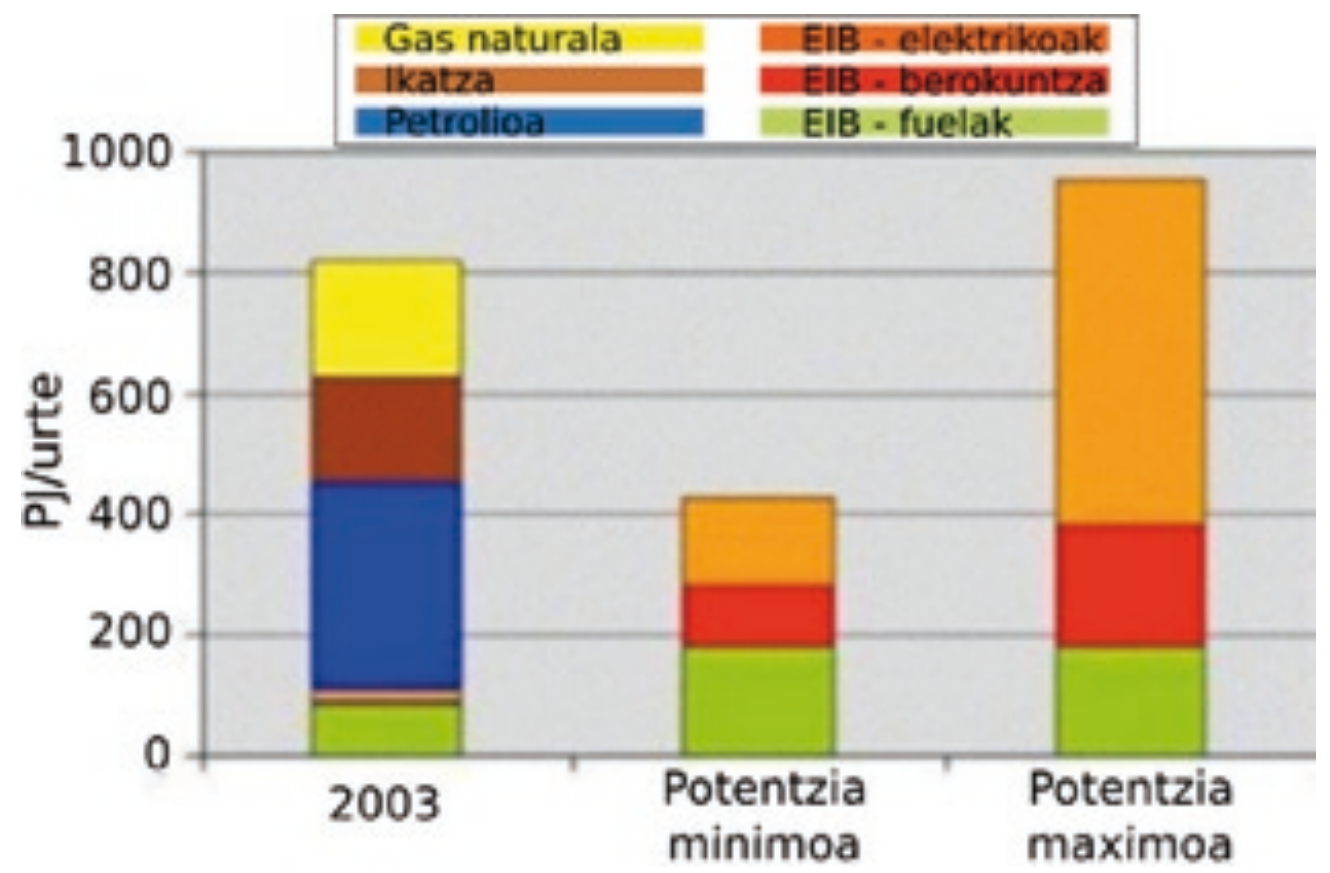

1. irudia

Energia berriztagarrien potentziala 2003ko kontsumoarekin alderatuta, Lund 2007 (913 or.) lanetik egokitua 
Laburbilduz, hauek dira Lunden lanaren emaitzak:

-Elektrizitatea. Haizea, eguzki-energia fotovoltaikoa eta olatuak. 40$160 \mathrm{TWh} /$ urtean.

- Beroa. Eguzki-energia termikoa (etxe indibidualetan eta auzo-berokuntzan) eta geotermia. 100-200 PJ/urte (1 PJ = $10^{15}$ joule).

- Biomasa-erregaia. Lastoa, egurra, zaborra ${ }^{3}$, biogasa eta energia-landaketak. $182 \mathrm{PJ} /$ urte.

Horietan guztietan, geotermia eta itsasoko haize-energiaren ekarpenak nabarmendu behar dira batez ere; bero-potentzialaren \% 50 geotermiaren bidez lortu zuten, eta elektrizitate-potentzialaren \% 62 itsasoko haize-energiaren bidez. Biomasaren kasuan, energia-landaketetatik eratorritako materia organikoa, lastoa eta egurra (pelletizazioaren bidez, esaterako) erabiltzen dira batik bat erregai gisa.

\section{Hego Euskal Herriaren egungo egoera}

Danimarka maiz aipatu izan da adibide eredugarri gisa. Izan ere, Danimarka Europako herrialde aurreratuenetako bat da alderdi askotan, tartean energia-subiranotasunean eta energia berriztagarrien erabileran. Hego Euskal Herriak baditu Danimarkarekin antzekotasunak Nafarroa Garaiko nahiz EAEko estatistikei begiratuta: Barne Produktu Gordina Europako batez bestekotik gorakoa izatea (EUROSTAT 2016), baztertze- eta pobrezia-egoeran daudenen portzentaje urriak izatea edo erdi- zein goi-mailako hezkuntza eta osasun-zerbitzuetan indize onak erakustea (Europar Komisioa 2016). Hala ere, HEHk (Hego Euskal Herriak) baditu gabezia garrantzitsuak Danimarkarekin alderatuz gero, izan Danimarkaren aurrerapen-maila altua delaeta edo HEHren maila baxuagatik. Energia-subiranotasunari eta energia berriztagarrien erabilerari dagokionez, HEHren egoera bereziki kezkagarria da, beheko taulan ikus daitekeen bezala, ez alde bakarreko estrategiaz estatu independente bat sortu nahi dutenentzat bakarrik, baita aldebikotasunetik identitate propioaren garapena eta aberriaren ongizatea bermatu nahi dituztenentzat ere. Paradoxikoa den arren, Nafarroa Garaiak ez du hainbeste haizatu estatu-egitura burujabearen aldarria, eta haren energiaren kudeaketaren oinarri erreala askoz irmoagoa da balizko burujabetza-prozesu bati begira.

\footnotetext{
${ }^{3}$ Erre daitekeen zabor organikoa —ez pneumatikoak, plastikoak edo gisa horretako produktu toxikoak-, egungo erraustegietan edo zementu-fabriketako galdaretan erabiltzen den gisan.
} 


\section{1. taula}

Nafarroa Garaiko, EAEko, Hego Euskal Herriko, Espainiako, Danimarkako eta Europar Batasuneko ('EB 28' taulan) datuak. Taulan, 'pc' laburdurak per-capita esan nahi du

\begin{tabular}{|c|c|c|c|c|c|c|c|c|c|c|c|c|}
\hline 306 & \multicolumn{2}{|c|}{ row } & \multicolumn{2}{|c|}{ froimeis } & \multicolumn{2}{|c|}{ Fondivis } & \multicolumn{2}{|c|}{ IN } & \multicolumn{2}{|c|}{ Steme Serth } & \multicolumn{2}{|c|}{ korst 5} \\
\hline Bukminis |mither & \multicolumn{2}{|c|}{$50 \mathrm{se}$} & \multicolumn{2}{|c|}{ ses } & \multicolumn{2}{|c|}{ thes } & \multicolumn{2}{|c|}{2.57} & \multicolumn{2}{|c|}{ ans } & \multicolumn{2}{|c|}{26} \\
\hline 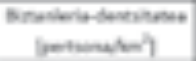 & \multicolumn{2}{|c|}{1314} & \multicolumn{2}{|c|}{1915} & \multicolumn{2}{|c|}{ vas } & \multicolumn{2}{|c|}{ mess } & \multicolumn{2}{|c|}{413} & \multicolumn{2}{|c|}{15031} \\
\hline 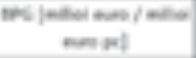 & Hosesw & meisas & มnल $=$ & asepi is & 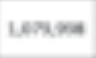 & $2 x \times a=$ & $\omega r k$ & nusa $x$ & Mass & masan & D., & mans \\
\hline 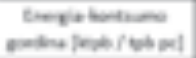 & Mavas & 120 & 16m & $2 \%$ & IXe日 & 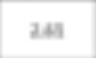 & $6 \times 1$ & 200 & 2010 & 317 & N.Sa & $2 w$ \\
\hline emplebintims! & vatury & 231 & 18⿲es & 245 & Nasi & 13 & $\operatorname{ses} 4$ & 238 & Las & $2 n$ & sas & 265 \\
\hline 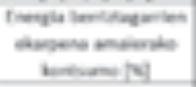 & \multicolumn{2}{|c|}{$16 \%$} & \multicolumn{2}{|c|}{$x=$} & \multicolumn{2}{|c|}{ 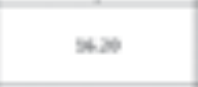 } & \multicolumn{2}{|c|}{720} & \multicolumn{2}{|c|}{24.5} & \multicolumn{2}{|c|}{$\mathrm{An}$} \\
\hline 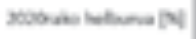 & \multicolumn{2}{|c|}{30} & \multicolumn{2}{|c|}{$\approx$} & \multicolumn{2}{|c|}{$\approx$} & \multicolumn{2}{|c|}{30} & \multicolumn{2}{|c|}{$x$} & \multicolumn{2}{|c|}{$=$} \\
\hline 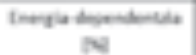 & \multicolumn{2}{|c|}{3400} & \multicolumn{2}{|c|}{ 13: } & \multicolumn{2}{|c|}{$x=0$} & \multicolumn{2}{|c|}{$n \infty x$} & \multicolumn{2}{|c|}{$k \infty$} & \multicolumn{2}{|c|}{ nest } \\
\hline
\end{tabular}

Horrez gain, HEHk baditu beste herrialde batzuek, esaterako Danimarka edo Espainiak, ez dituzten oztopo edo zailtasun batzuk energia berriztagarriak eskala handian baliatzeko. Izan ere, HEH lurralde txikia da, geografikoki oso malkartsua, biztanleria-dentsitate handikoa eta industria-maila altua duena. Biztanleria-dentsitate altuak eta, bereziki, industria-maila altuak energia-kontsumo oso altua dakarte. Taulan ikus litekeen bezala, energia-kontsumoan Danimarkaren parekoa da pertsonako energia-kontsumoa HEHn. Aldiz, biztanleria-dentsitatea dezente altuagoa da (batez ere EAEren kasuan). Hori gutxi balitz bezala, HEHren geografia malkartsuak muga fisiko nabarmenak ezartzen ditu, energia berriztagarriek gainontzeko energia-iturriek baino lur-zati askoz zabalagoak behar baitituzte energia kantitate parekoa sortu ahal izateko. Dena ez da desabantaila, ordea. Industrializazio-gradu altua abantaila handia izan liteke zenbait teknologiaren garapenerako eta eraikuntzarako eta, gainera, garapen horrek hamaika onura ekonomiko ekarriko lizkioke lurraldeari.

Ondorioz, baliteke HEHn zailagoa izatea mundu-mailan zein Europan gero eta errealistagoa eta beharrezkoagoa dirudien \% 100 berriztagarria den energia-sistema garatzea. Hala ere, zailtasun hori ezin da izan inola ere gaur egun HEHk, eta bereziki EAEk, energia berriztagarrietan dituen hutsune ikaragarriak justifikatzeko aitzakia. EAEri inguruan norbaitek erakusten badio eredu gertuko eta errealista, Nafarroa Garaiak erakusten dio. Alegia, instituzionalki batutako balizko HEHn, Nafarroa Garaiaren energia-egoera abantaila estruktural nagusietako bat litzateke, dudarik gabe, garapen jasangarriago baterako trakzio-indarra bertatik letorkeelako, eta agian ildo estrategiko argiagoa marrazten lagunduko lukeelako. Hau da, finean, garapen jasangarrirako 
estrategia martxan jartzekotan, bere oinarriak ondo landu eta gurera egokitu behar dira. Izan ere, oinarri horiek ondo definituak daude aspalditik.

\section{Garapen jasangarriaren oinarriak}

Garapen Jasangarrirako Estrategia bultzatzen dutenek normalean hiru arazo teknologiko nagusi izaten dituzte:

1. Energia metatzea eskari-lekuan.

2. Eraginkotasun-hobekuntzak energia-produkzioan.

3. Erregai fosilak ordezkatzea energia berriztagarrien iturrien bidez.

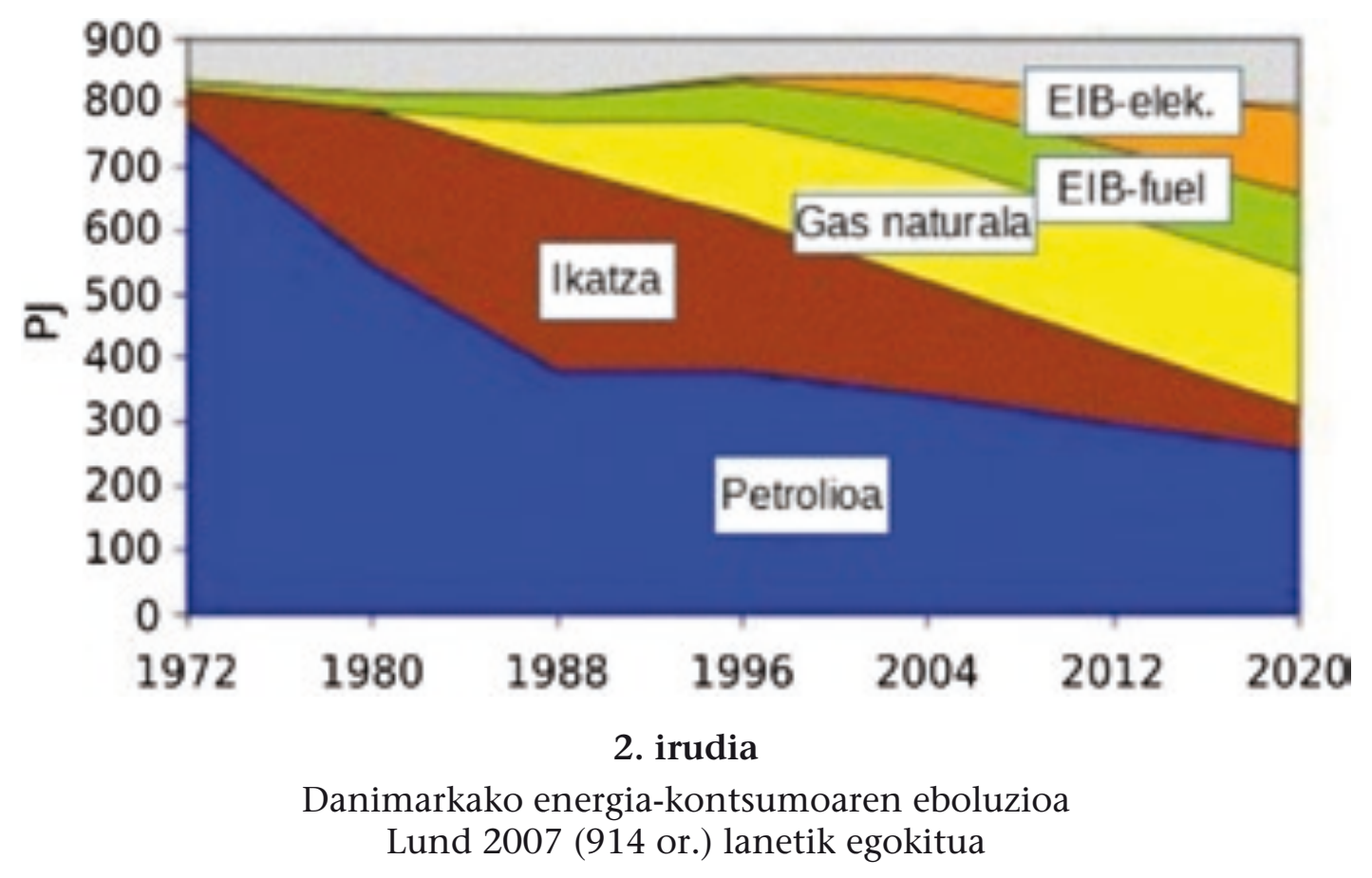

Egiazko plan zabal batek, beraz, nahitaez izan behar ditu EIBak energiasistema orokorrean integratzeko bi estrategia: batetik, energia-metaketa eta, bestetik, efizientzia-hobekuntzak. Erronka nagusia da sarean gero eta energia berriztagarri gehiago sartzea. Garrantzizkotzat jotzen den arren, mundumailan oso gutxi erabiltzen da proportzioan oraindik. Erabiltzen den gutxi hori energia hidraulikoa eta biomasa da nagusiki, azkena batez ere Afrikan eta Hego Amerikan. Lurralde batzuetan hazkuntza esanguratsuak izan dituzten arren, haizearekin eta eguzkiarekin lotutako teknologiek parte oso txikia dute mundu-mailako energia-sorkuntzan. Danimarka da, zentzu horretan, EIBen aldeko apustu garbia egin duen herrialde bakarrenetakoa. Izan ere, 90eko hamarkadatik aurrera energia-kontsumoa gutxitzeaz gain, berriztagarrien kuota energia guztiaren laurdena izatera iritsi da (ikus 2. irudia eta 
1. taula). Energia berriztagarriak ugaldu beharraren baitan, bi erronka nagusi daude:

— Aldizkako energia-baliabideak — «intermitenteak»; batez ere, haizea eta eguzkia-, integratu behar dira sarean;

- Garraio-sektorea estrategia hauetan sartu behar da.

Teknikoki hitz eginez, Lunden ustez oinarri horiek eta ardatz nagusiok pauso zehatzetan egikaritu daitezke modu mailakatu eta ez-muturreko batean. Hona hemen Lunden lanean giltzarri diren zenbait puntu:

-Aurrezpena: \% 10eko jaitsiera elektrizitate-kontsumoan, etxebizitzen berokuntzan eta industriaren bero-erabileran.

- Efizientzia. Bero-argindar konbinazio eraginkorragoa BEPK (Bero eta Elektrizitate Produkzio Konbinatua) deritzotenetan. Hots, bero- eta elektrizitate-produkzioen efizientzia ahalik eta gehien garatzea kogenerazio-prozesuetan, eta, horretarako, barreiaturik dauden bero-fokuak elektrizitatea sortzeko aprobetxatzea (industrian, esaterako); edo, alderantziz, argindarra sortzeko gune handiak dauden lekuetan argindar hori bero gisa metatzeko puntuak ezartzea. Bilakaera hori, hasiera batean, existitzen diren lurrun-turbinak hobetuz lor daiteke, galtzen den beroa auzo-berokuntzarako aprobetxatuz, adibidez. Baina, azken finean, energia-sareko kokapen egokienetan BEPK txiki ugari eraikitzea litzateke benetako erronka.

—EIB: biomasa erregaitzat gehiago erabiltzea eta eguzki-energia termikoa gehitzea auzo-berokuntzan, plaka hibridoekin konbinatuz elektrizitatea ere sortu ahal izateko. ${ }^{4}$

Aurrezpena, efizientzia eta EIBak hazten diren heinean, energiaren integrazioa bihurtzen da arazo, eta, arazoa txikiagoa izan dadin, teknologia malguak modu adimentsuan (smart esan ohi da adimen artifizialaren baitan) erabili behar dira, une oro dagoen energia-produkzioa eta -kontsumoa erregulatzeko.

- Garraioa. Garraiorako erregai fosilak elektrizitateak ordezakuto lituzke. Kalkuluen arabera, egoerarik probableenean $1 / 3$ proportzioan murriztu behar da elektrizitate/petrolio-energia garraio-sistemari eusteko. Malgutasun horren baitan, auto elektrikoek pila moduan ere funtziona dezakete geldirik daudenean, argindarra sareratzeko (saltzeko) eta energia kargatzen (erosten) ari diren beste auto batzuk elikatzeko.

\footnotetext{
${ }^{4}$ Hego Euskal Herrian, hainbat enpresa aitzindari dira eguzki-plaka hibridoen fabrikazioan. Etxerako ur beroa metatzeko ez ezik, argindarra sortzeko ere balio dute. Gainera, kanpoko beroa xurgatzean plaka fotovoltaikoa hoztu egiten da, eta, ondorioz, bere errendimendua handitu.
} 
— BEPK malguak. Hurrengo pausoa litzateke bero-energia erregulatzeko BEPK planta txiki ugari ipintzea eta berokuntza-sistemako hoditerian bero-ponpa kopuru handiak gehitzea. Horien instalazioak eta mantenuak lanpostu berriak sortzea ekarriko luke.

- Haizearen eta elektrolizatzaileen erregulazioa: azkenik, elektrolizatzaileak gehitu behar lirateke sisteman energia metatzeko, eta, era berean, elektrizitate-sarea haize-turbina kopuru handiak integratzeko (tentsiorako eta maiztasunerako) egokitu beharko litzateke.

\section{Hego Euskal Herriaren burujabetza energetikorako aukerak}

Eurostat Europako estatistika-zentroaren arabera, Europako biztanleriak gaur egungoaren oso antzekoa izaten jarraituko du hurrengo hiru hamarkadetan (EUROSTAT 2016). Beraz, energia-beharrek ere antzekoak izaten jarraituko dutela esan liteke. Hala ere, kontsumoa murriztea ezinbestekoa izango da. Energia-aurrezpena \% 10ean finkatzen du Lundek bere lanean, baina aurrezpen hori handiagoa izatea ere posible litzateke. Izan ere, \% 100 berriztagarria den sisteman, energia-kontsumoa nabarmen murriztuko litzateke, lau arrazoi nagusi hauengatik:

— Energia sortzeko teknika berriztagarriek efizientzia altuagoa izango lukete.

- Garraioan erabiliko liratekeen hidrogeno-zelulen efizientzia altuagoa izango litzateke erregai fosil konbentzionalekin alderatuta.

- Uranioa, ikatza, petrolioa, gasa eta antzeko lehengaiak ustiatzeko beharrezko den energia ez litzateke beharko ${ }^{5}$.

— Energia-efizientziaren aldeko politiken ondorioz kontsumo-murrizketa sustatuko litzateke.

Lau faktore horien ondorioz, kontsumoa \% 42,5 murriztea lor liteke (Jacobsen et al. 2017). Gainera, egungo eraikuntzak efizienteago izateko egokituko balira, kontsumo-murrizketa are handiagoa izango litzateke. Eraikuntzak egokitzeaz gain, auzoetako berokuntza-sareak sortzeak eta horietan instalatutako kogenerazio-zentroek ere energia-kontsumoa murrizteko bultzada garrantzitsua ekarriko lukete.

Energia berriztagarrietan oinarritutako sistema elektriko bat diseinatzeko, oinarrizkoa da etorkizuneko kontsumoa ezagutzea. Dena dela, etorkizuna aurreratzea ezinezkoa denez, ezinbestekoa da hainbat kontsumo-egoera aurrei-

\footnotetext{
5 Ikus EII indizearen eztabaida 7. atalean. Iritsiko da une bat non petrolio-putzuak hain sakon eta iristeko hain leku zailetan egongo diren, ezen erregai-masa ateratzeko behar izango den energia-masa putzuak emango duena baino gehiago izango den.
} 
kustea. 2015. urteko kontsumoan oinarrituz (ikus 1. taula), lau egoera aurreikusten ditugu lan honetan:

I. Energia-kontsumoa \% 10 igotzea: 106,45 TWh.

II. Energia-kontsumoa \% 10 murriztea: 87,10 TWh.

III. Energia-kontsumoa \% 30 murriztea: 67,47 TWh.

IV. Energia-kontsumoa \% 50 murriztea: 48,39 TWh.

Era horretan, HEHren energia-kontsumoa etorkizuneko edozein egoeratara egokitu ahal izateko gaitasuna aztertuko dugu, garapen jasangarrirako oinarriak kontuan izanik, eta HEHren ezaugarri sozial, ekonomiko eta geografiakoak ahaztu gabe. Energetikoki burujabe izateko, ezinbestekoa izango da hainbat energia-iturri konbinatzea. Ondorioz, EIB bakoitzak HEHn duen potentziala ezagutzea beharrezkoa da.

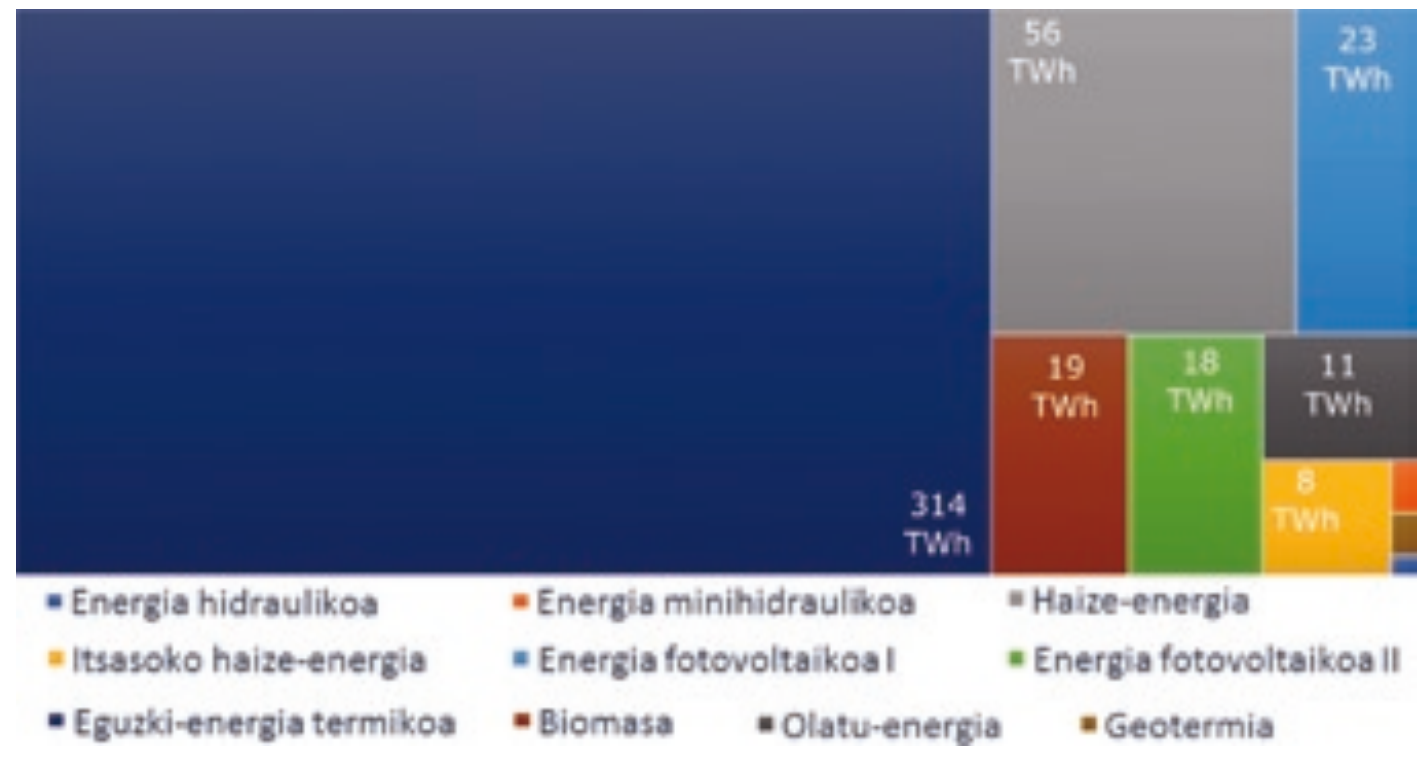

3. irudia

Hego Euskal Herriko energia-iturrien potentziala ehunekoetan García et al. 2005 lanean oinarritua. Energia minihidraulikoari, geotermiari eta hidraulikoari dagozkien energia-potentzialak 8 GWh, 7 GWh eta 1 GWh dira, hurrenez hurren

EIBetatik lor litekeen energia-maila altuena definitzeko sorkuntza-zorua terminoa definitzen dute Garcíak eta bere kideek Greenpeacerentzat eginiko lanean (García et al. 2005). Lan horretan, EIB ezberdinen sorkuntza-zorua kuantifikatzen dute estatu espainiarrean, EAE eta Nafarroa Garaia barnean hartuta. Bi autonomia-erkidego horien sorkuntza-zoruak konbinatuz lortzen da goiko irudian azaldutako HEHko energia berriztagarrien potentziala. Bertan, eguzki-energia termikoa, haize-energia, fotovoltaikoa (fotovoltaikoa 
I eraikuntzetan integratutako fotovoltaikoari dagokio eta fotovoltaikoa II bestelako instalazio fotovoltaikoei) eta biomasa dira nagusi. Aipatzekoa da, halaber, sorkuntza-zoru horiek kuantifikatzeko eremu babestuetan edo balio natural handiko eremuetan berriztagarriak instalatzeko dauden mugak kontuan hartuta daudela. Horrez gain, iturrien arteko bateraezintasunak ere kontuan hartu dira.

Iturrien sorkuntza-zoruak gehituta, urteko 450 TWh baino gehiago sortzeko gaitasuna aurreikusten dute Garcíak eta bere kideek HEHn; 2015eko kontsumo totala baino 4,66 aldiz energia gehiago. Hala ere, sorkuntza-zoru horiek kalkulatzean, lurraldearen azalera ia osoa energia-sorkuntzarako erabiliko litzatekeela aurreikusten dute, eta horrek jasangarritasun-irizpideak kolokan jarriko lituzke.

Beraz, ezinbestekoa da potentzial hori ahalik eta era jasangarrienean erabiltzea gizartearen energia-beharrak asetzeko. Jasangarritasun hori bermatu ahal izateko, ezinbestekoa da aurreko atalean aipatutako irizpideak jarraitzea, kontuan hartuz teknologia bakoitzaren lurraren okupazio-maila, energia-sorkuntza eta kontsumo-puntuen arteko gertutasuna, eta EIBen dibertsifikazioa.

Jasangarritasun-irizpide horietan oinarrituz, HEHren ezaugarrietara ondoen egokitzen diren teknologiak hauek dira: hidraulikoa, haizea (lurrekoa zein itsasokoa), eguzki-energia fotovoltaikoa zein termikoa eta biomasa. Teknologia horietako bat edo beste hautatzeko, EII indizea izan liteke kontuan hartu beharreko ezaugarrietako bat. Indize hori erreferentziatzat hartzen da lan askotan; izan ere, ekonomian oinarritutako beste indize batzuen aldean energiaren sorkuntza/inbertsio-ratio adimentsional bat ezartzen du; diruaren edo kWh-en balioaren fluktuazio historiko eta geopolitikoetatik at dagoen arrazoia, alegia (Ulazia 2016, Murphy \& Hall 2010).

Okupazioa minimizatuko lukeen estrategiak gaur egungo HEHren itxura asko ez aldatzea bermatuko luke, eta ahalik eta gutxien eraldatuko lituzte gure paisaiak. Energiaren dibertsifikazioak, berriz, energia-iturri gutxi batzuen menpekotasunetik ihes egiten lagunduko luke. Azkenik, sorkuntzapuntuak eskari-puntuetara hurbiltzeak energia garraiatzerakoan izandako galerak murriztuko lituzke, autokontsumoaren eta eskala txikiko instalazioen hazkundea ekarriko luke, eta energiaren demokratizazio-prozesua ahalbidetuko luke.

Lau ardatz horiek kontuan izanik, hidraulikoa (handia zein minihidraulikoa), geotermia eta eraikuntzetan integratutako fotovoltaikoaren potentzial osoa erabiltzea gomendatzen da. Izan ere, zabaltzeko aukerarik ez duen hidrauliko handia kenduta, gainerako hiru iturrien potentziala eskala txikiko instalazioen bitartez aprobetxatu beharko litzateke; horrela, okupazioa minimizatuko litzateke (instalazio geotermikoek okupatutako lurraldearen \% 0,0002 beharko litzateke soilik) eta autokontsumoa bultzatuko. Energia 
geotermikoa erabiltzeko aukera interesgarrienetako bat auzo-berokuntza geotermikoa izan liteke, non eraikuntzetarako beroa, gasaren edo biomasaren bidez lortu ordez, lurpeko beroa aprobetxatuz lortuko litzatekeen. Europan era horretako 240 instalaziotik gora daude, eta 2020ko energia-helburuak lortzeko bidean Europar Batasunak proposatzen eta laguntzen duen tekniketako bat da.

Horrez gain, biomasaren potentzial osoa erabiltzea ere oso aproposa izan liteke \% 100 berriztagarria den energia-sistema batean. Zeren, biomasak, biltegiratzeko duen erraztasuna dela medio, eskari-puntuetan edo gainontzeko iturrien eskasiaren aurrean erabili ahal izateko gaitasuna du. Gainera, elektrizitatea sortzeko erabiltzeaz gain, berokuntzarako ere erabilgarria izan liteke, berogailuentzako pelletak sortuz, adibidez. Horretan ere eskala txikiko instalazioek berebiziko garrantzia izango dute. Baina biomasaren potentziala behar bezala aprobetxatzeko, pellet horien barne-merkatua indartu beharko da.

Energia-iturri hauek soilik erabiliz, ordea, 43 TWh soilik sortu ahal izango genituzke urteko, eta ezin izango lirateke ase etorkizuneko egoera positiboenerako energia-beharrak ere. Beraz, beste iturri batzuen ekarpena beharrezkoa da. Gainontzeko iturrien artean, haize-energia (lurrekoa batez ere) da bereziki interesgarria, bere EII indize baxua eta gaitasun-faktore altua direla eta. Nolanahi ere, potentzia-unitateko lurraldearen okupazio-tasa handienetakoa duen iturria denez, potentzial osoaren zati bat soilik erabiltzea gomendatzen da. Kasu horretan, lurreko potentzialaren \% 30 (7,5 GWeko potentzia) eta itsasokoaren \% 10 (400 MW) erabiltzea proposatzen da. Zifra handiak diruditen arren, lurralde osoaren \% 15 soilik okupatuko lukete haize-energiaren instalazioek (2005. urteko haize-energiaren turbinen potentzia-maila kontuan hartuz, zeina gaur egungo turbinena baino dezente baxuagoa den). Gainera, kontuan hartu beharrekoa da haize-energiaren instalazioak lurraren beste erabilera/jarduera batzuekin bateragarriak direla, izan abeltzaintzarekin, nekazaritzarekin edo beste iturri bateko energia-sorkuntzarekin (fotovoltaikoarekin, adibidez).

Itsasoko haize-energiari emandako portzentaje baxuaren arrazoia teknologiaren garapen falta da. Hego Euskal Herriko kostaldearen ezaugarriak direla eta - kostatik gertu topatzen diren sakonera handiak batez ere-, oraindik guztiz garatu gabeko haize-energiaren turbina flotatzailea beharko litzateke, eta teknologia horren potentziala oraindik ikusteko dago. Hala ere, esan beharra dago azken urteetako aurrerapenek etorkizun oparoa aurreikusten diotela haize-energiaren turbina flotatzaileari, eta Kantauri itsasoko kostaren potentziala eta batimetria kontuan hartuta kalkulatu den potentziala alimalekoa dela: muga legalak eta fisikoak kontuan hartuta, $40 \mathrm{GW}$-eko potentzial instalatuarentzako lekua legoke Galiziatik Gipuzkoaraino; hau da, espazioaren okupazioa \% 10ean ipinita, zentral nuklear baten adinako pro- 
dukzioa geneukake euskal itsasoari dagokion zatian turbina flotatzaileekin (Ulazia et al. 2016). Horrek, gainera, jarraipena emango lioke Hegoaldean industria nautikoak eta ontziolek izan duten garrantzia historikoari; egun kolokan dagoen sektore hain garrantzitsua indartuko luke, eta, inguruko makina-erremintaren sarean, gertuko merkatu bat sortuko luke haize-erroten piezentzat eta egitura flotatzaileen elementuentzat. Esan beharrik ez dago hemen pilatutako jakintza eta espezializazioa esportagarria litzatekela, gainera.

Itsasoko haize-energia aintzat hartu gabe, 61 TWh sortzeko gaitasuna izango genuke HEHan urtero energia hidraulikoaren, fotovoltaiko integratuaren, geotermiaren, biomasaren eta haizearen bitartez. Horrekin, IV. egoerarako nahikoa energia izango genuke eta III. egoera asetzetik oso gertu geundeke. Dena den, I. eta II. egoeretako eskaria asetzeko beste iturri batzuen ekarpena ezinbestekoa izango litzateke. Kasu horietan, behar adinako energia sortzeko gaitasuna izan arte energia fotovoltaikoa zein termikoa gehitzea komeniko litzateke. Hala ere, energia termiko integratua - hau da, eraikuntzetan instalatutako eguzki-energia termikoa- izatea oso gomendagarria litzateke. Izan ere, eguzki-energia termiko horren bitartez etxebizitzetako zein komertzioetako ura berotzeko gaitasuna izango genuke elektrizitaterik erabili gabe.

Azkenik, gainerako energia motak ere kontuan hartu behar dira, energia berriztagarrien ekarpena maximizatu nahi bada, ezinbestekoa izango delako iturri mota guztien ekarpena. Talde horretan sar genitzake olatuen energia edo geotermia. Olatuen energia potentziala dezentekoa da Hegoaldeko kostan. EAEko 2030. urterako planean $60 \mathrm{MW}$-eko potentzia duen parke sorta bat izatea espero da. Itsasoko haize-energiaren kasuan bezala, oraindik ere erabat garatu gabeko teknologia den arren, etorkizunean zeresan handia izan lezakeela uste da. Besteak beste, olatuen energia gainontzeko iturriena baino egonkorragoa izatean, oinarriko iturri gisa erabiltzeko bereziki egokia izan liteke sare elektrikoan.

Hurrengo irudian erakusten den kasurako, energia fotovoltaiko ez-integratuaren potentzialaren \% 20 eta termikoaren \% 10 erabiltzea aukeratu da. Kasu horretan, I. egoerarako oraindik 10 TWh inguruko energia faltako litzateke, baina gainontzeko egoera guztietarako (2015. urteko kontsumo-mailarako barne) nahikoa energia sortzeko gaitasuna duen energia-sarea izango luke HEHk.

Hala ere, energia berriztagarriek eskariaren \% 100 estaltzen duten sistema elektriko batean, iturri berriztagarrien aldizkakotasuna dela eta, ezinbestekoak izango dira biltegiratze- azpiegiturak, alde batetik, eta inguruko herrialdeekin interkonexio elektriko sendoak, bestetik. Energia biltegiratzeko beharrezko azpiegiturak, beste behin ere, eskala txikian edo handian egin litezke. Azken urteetan bateria elektrikoen prezioa jaitsi egin da, eta datozen 
urteetan ere joera berbera mantentzea espero da. Horrek autokontsumoko instalazio txikien erabilera eskuragarriago jartzeaz gain, sistema osoa egonkortzen lagun dezake, eta biltegiratze-azpiegitura handien beharra murriztu egingo da. Energia biltegiratzeko eskala handiko aukeren artean, berriz, gaur egun gasa biltegiratzeko erabiltzen den Gaviota plantaren antzeko egiturak erabiltzea litzateke aukeretako bat, bertan hidrogenoa edo aire konprimatua biltzeko. Urtegiak ere ponpatze-zentral gisa funtzionatzeko molda litezke, energia behar denean urtegiko ura turbinatuz eta elektrizitate-soberakinak daudenean ponpatuz. Biltegiratzeko baliabideak murritzak direnez, energia berriztagarrietan soilik oinarritutako sisteman interkonexio-sare zabal eta egoki bat behar litzateke, unean uneko eskariari erantzun ahal izateko. Euskal Herriaren kokagune geografikoa bereziki ona da, Espainia eta Frantzia bezalako bi estatu handiren tartean. Gainera, EHren (Iparraldea barne) egungo estatus juridikoa dela eta, interkonexio horiek onak dira jadanik. Izan ere, datozen urteetan interkonexio-sareak sendotzeko planak eginak daude; Akitania eta EAEren arteko urpeko interkonexioa, adibidez (Eusko Jaurlaritza 2016).

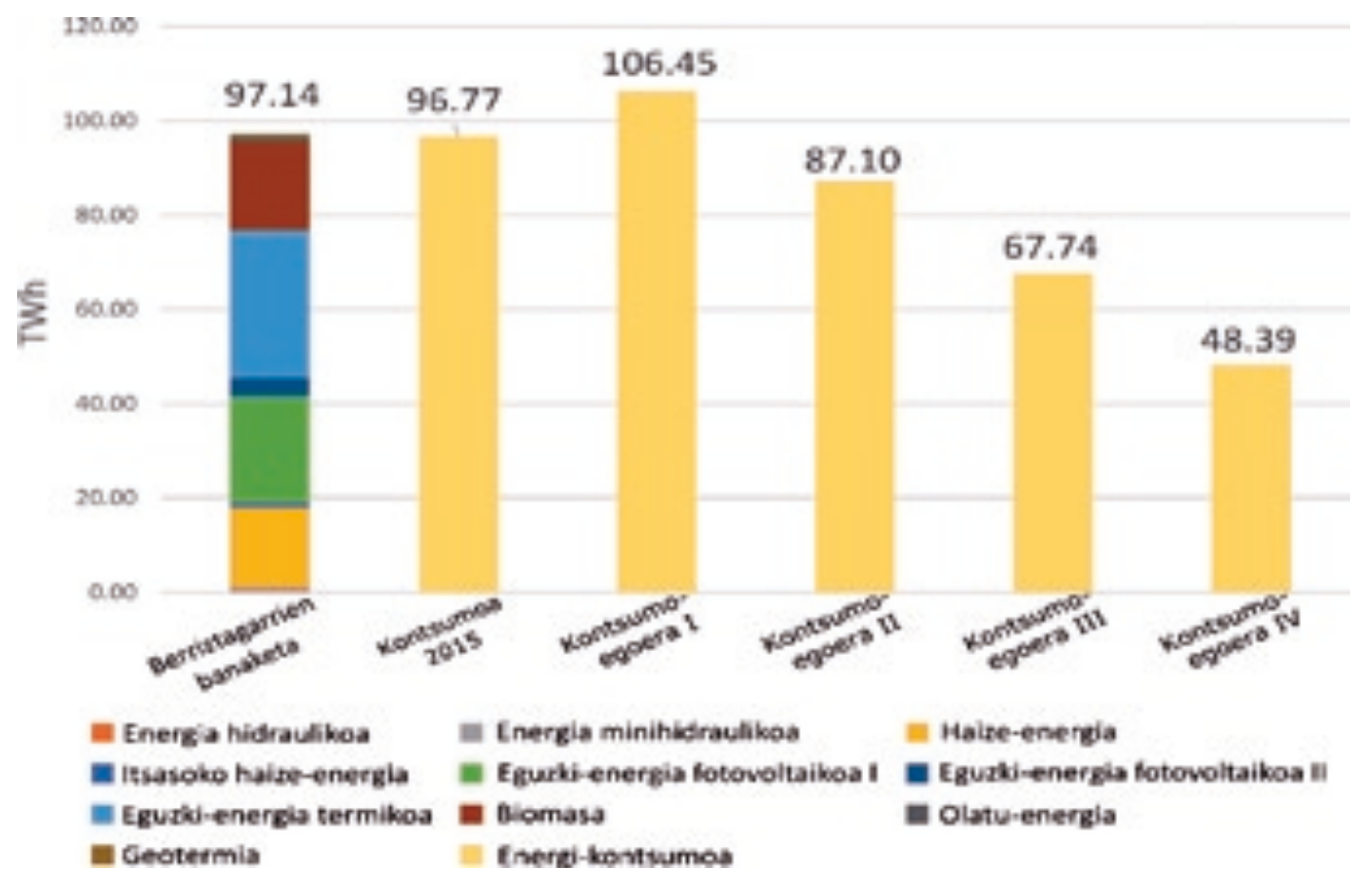

4. irudia

Egoera ezberdinetako kontsumoa eta proposatutako berriztagarrien banaketa

Energia-sistema \% 100 berriztagarria izateko transformazioa klima-aldaketa ahal den heinean saihesteko ideiatik datorren arren, bestelako onurak ere baditu, maila ekonomikoan zein sozialean, eta HEH bezalako lurraldeek 
jasango lituzkete onura horiek bereziki. Ekonomikoki, \% 100 berriztagarria den sistema garatzeko bidean, mundu-mailan 52 milioi lanpostu sor litezkeela iradoki du orain gutxi argitaratutako ikerketa batek (Jacobsen eta al. 2017). Lanpostu horien zati handi bat lanpostu kualifikatuena izango litzatekeela ere kontuan hartu beharko litzateke. Iturri konbentzionaletatik berriztagarrietara pasatzean, ia 28 milioi lanpostu galtzea ere espero da mundu osoan, baina HEHk ez luke kalte hori pairatuko, euskal industria ez baita petrolioaren, gasaren edo ikatzaren ustiapenean oinarritzen.

Horrez gain, HEHko industria aurreratua energia berriztagarrientzat behar diren azpiegiturak sortzeko hautagai nagusietakoa izan liteke. Ikerketaren aldeko apustu sendoa eginez gero, Danimarkak egin duen bezala, energia berriztagarrietarako trantsizioaren abangoadian egon litekeen lurraldea izan liteke HEH. Ikerketara zuzentzen den barne-produktu gordinaren (BPG) ehunekoak alderatzen badira, ikus liteke HEHk oraindik baduela zer hobetu. EAEn BPGaren \% 1,84 eta Nafarroa Garaian \% 1,64 inbertitzen da; Danimarkan, berriz, \% 3tik gora. Eta \% 2ko mugatik gora (oso gora askotan) daude berriztagarrien lehian aurkari izan litezkeen beste estatu batzuk; Frantzia, Suedia, Finlandia, Belgika, Alemania edo Austria, esaterako (EUSTAT). Izan ere, transformazio horrekin irabaziko duten herrialdeak teknologia sortzen liderrak diren herrialdeak izango dira (Goldthau 2017).

Gainera, energia berriztagarrietarako jauziaren eragina haratago doa, aberastasunaren berdintasunezko banaketa bermatzeko aukera ematen baitu (Girardet \& Mendonca 2009). \% 100 berriztagarria izango den sistemak energiasorkuntza eta -kontsumoa deszentralizatzeko aukera paregabeak eskaintzen ditu. Horrela, orain arte kontsumitzaile huts izandako herritar zein enpresa txikiak produzitzaile/kontsumitzaile papera hartzera pasako lirateke, eta herritarrak energia-sistemaren transformazioaren lehen lerrora. Horrek energia berriztagarriak garapen sozio-ekonomikorako eta aberastasunaren banaketarako tresna bihurtzen ditu. Europan zein munduan zehar jada errealitatea da energia berriztagarrien eragina, bai kooperatiba gisa, bai enpresa txikien bitartez, edo norbanakoek eraikitako EIBen egiturak erabiliz, eta azpiegiturak pixkanaka baina etengabe ugaritzen doaz.

Bestalde, herritarren parte-hartze aktibo horrek, lehenik eta behin, gizarte gisa ditugun energia-beharren inguruko kontzientziazioa ekarriko luke, eta eragin zuzena izango luke kontsumo-murrizketan. Horrez gain, kontzientziazio-prozesu horrek energia berriztagarrien onarpen-maila handitu egingo luke. Lan honetan aztertu ez arren, EIBen inplantaziorako giltzarri da.

Beraz, beharrezko baliabide naturalak, industria eta giza kapitala baditu HEHk berriztagarria eta jasangarria izango den sistema elektrikora jauzia egiteko. Erabakiak hartzen hastea besterik ez da falta. Orain arte egindako politikek, ordea, Nafarroako Foru Erkidegoko gobernuak egindakoek salbu, ez dute bide horretan pauso sendoak ematen lagundu. Izan ere, EAEk 10 ur- 
teko atzerapena dakar bere buruari ezarritako helburuetan (Eusko Jaurlaritza 2016).

Hala ere, esan beharra dago EAEko zein Nafarroako Foru Erkidegoko gobernuen ahalmenak urriak direla zentzu askotan. Esaterako, autokontsumoari dagokionez, Espainiako legea mundu-mailan dagoen legerik murriztaileenetakoa da, autokontsumorako laguntzak eman beharrean, zailtasunak jartzen baititu. Lege horrek autokontsumorako aukerak erabat mugatzen ditu, bereziki autokontsumoaren errentagarritasun ekonomikoa erabatekoa ez denean. Autokontsumoa eta herritarra gehiago babesten dituzten legeak ezarri dituzten estatuetan, Alemanian edo Danimarkan kasu baterako, baliabideak urriagoak izanagatik, autokontsumorako instalazioak etengabe ugaltzen jarraitzen dute, eta horrek herrialdearen EIBen erabilera handitu egin $\mathrm{du}$ eta dependentzia energetikoa murriztu. Gauza bera gertatzen da eskala handiko energia berriztagarrien zentralak ezartzerako orduan ere. Termino ekonomiko hutsetan oinarritutako sistema batean HEHk ez du bere energia berriztagarrien sarea handitzeko aukerarik izango, edozein instalazio berri baliabidea errentagarriagoa den eremuetan instalatuko baita. Energia-estrategia propioa izateak eta estrategia hori aurrera eraman ahal izateko mekanismoak izateak soilik bermatzen du baliabide baxuagoko lurraldeetan energia berriztagarriak errentagarri egitea. Danimarka edo Alemaniaren eguzki-energiaren sektorearen kasua da, hain zuzen ere, horren adibiderik garbiena. HEHn estrategiak planteatzeko aukera izanagatik, estrategia horiek aurrera eramateko mekanismoak ez daude bere esku. Gainera, mekanismo horiek aldatzeko edo moldatzeko gobernu autonomikoen gaitasunik eza argi geratu da Katalunian ere: aldaketa klimatikoaren aurka bertako parlamentuan onartutako legea Espainiako Auzitegi Konstituzionalera eraman du Madrilgo gobernuak.

\section{Ondorioak}

Eredu jasangarri baterako bidea egiteko, argi dago EIBen aldeko apustu sendoa ezinbestekoa dela. Hori, egungo giza teknologiaren garapena ezagututa, ekosofiaren oinarri pragmatiko bat dela esan daiteke. EIBekin klima-aldaketari aurre egitea ez ezik, teknologia malguagoak eta deszentralizatuagoak dakartzaten jakintza-ildoen ugaltzearen aberastasunaz ekonomia banatuagoa eta gizarte berdintasunezkoagoa lor litezke. Eta, etorkizun geopolitiko multipolarrean daukagun ziurgabetasun erabatekoaren aurrean, HEHren dependentzia energetikoaren murrizketa beharrezkoa egikarituko litzateke. Gainera, hori jasangarritasuna errespetatuz egin daitekeela erakutsi da Danimarkako ereduarekin eta Lunden lan kanonikoarekin analogian. Baina, hori guztia aurrera eramateko erabakimena izateko, legalki aitortutako burujabetasun-maila baten jabe izatea ia ezinbestekoa dela erakutsi digu errealitateak, erabakimen argiz baina erabakitze-ahalmen gabe inguruko hiriek eta komunitateek jasan dituzten oztopoek horrela erakutsi baitigute. Alderan- 
tziz, burujabetasun nazionalaren eskaera historikoa ahulagoa izan duten komunitateek dependentzia energetikoa gehiago murriztu izana ere gertatu da; adibidez, Nafarroa Garaian. Ez da, beraz, berdina burujabetasunaren oinarri errealak eraikitzea eta independentziaz hitz egitea. Horregatik, (in)dependentziari buruzko edozein eztabaidak, praxi errealetik kanpoko lainoetan geratu nahi ez baldin badu, muinean izan behar du energia berriztagarrien inplementazio lokal eta deszentralizatuaren gaia. Zentzu horretan, energia berriztagarriak independentziarako eta gizarte berdintasunezkoago bateranzko teknologiak direla defenditzen da lan honetan, petrolioaren ingurukoa injustizia geopolitiko larriak eragiten dituen eta mundu monopolar bat sortzeko joera duen teknologia den gisan.

\section{Taula terminologikoa eta laburdurak}

\begin{tabular}{ll}
\hline \multicolumn{1}{c}{ Euskaraz } & \multicolumn{1}{c}{ Ingelesez } \\
\hline EIB (Energia Iturri Berriztagarriak) & RES (Renewable Energy Sources) \\
\hline Auzo-berokuntza & District Heating \\
\hline EII (Energia Itzulera Inbertitutakoarekiko) & EROI (Energy Return on Investment) \\
\hline $\begin{array}{l}\text { BEPK (Bero eta Elektrizitate Produkzio } \\
\text { Konbinatua) }\end{array}$ & $\begin{array}{l}\text { CHP (Combined Heat and Power Produc- } \\
\text { tion) }\end{array}$ \\
\hline Itsasoko haize-energia & Offshore wind energy \\
\hline
\end{tabular}

\section{Esker onak}

Lan honen bi egileek harremana dute Jesus Mari Larrazabalekin. Alain Ulaziak bere zuzendaritzapean egin zuen tesia eta Markel Penalba zumaiarra da, Larrazabalen jaioterrikoa. Urteetan Euskal Herrira arrazoimena ekartzeko egin duen lana eskertu nahi lukete bere erretiroan irakurtzeko interesgarria gerta lekiokeen testu honekin.

\section{Erreferentzia bibliografikoak}

Aarts, P. \& Renner, M. (1991), «Oil and the Gulf War». Middle East Report (MER) 171. 1991ko uztaila/abuztua. URL: https://www.merip.org/mer/mer171

AHMED, N. (2014), «Iraq invasion was about oil». The Guardian, 2014-03-20. URL: https://www.theguardian.com/environment/earth-insight/2014/mar/20/iraq-waroil-resources-energy-peak-scarcity-economy

Apaolaza, U., Apaolaza, E. \& GoikoetXea, J. (2016), Independentzia, demokrazia eta ekonomia. Manu Robles-Arangiz Institutua. 
BGR (2014), «Energy Study: Reserves, Resources and Availability of Energy Resources». Federal institute for Geosciences and natural resources. URL: http://www. bgr.bund.de/EN/Themen/Energie/Downloads/energiestudie_2014_en.pdf? blob=publicationFile $\& v=3$

BuckLey, N. (2016), «Sino-Russian gas deal: smoke without fire». Financial Times. URL: https://www.ft.com/content/eea4f2ec-16c0-11e6-b197-a4af20d5575e?mhq5j=e2

DAsGupta, R. (2018), «The demise of the nation state». The Guardian, 2018-04-05. url: https://www.theguardian.com/news/2018/apr/05/demise-of-the-nation-staterana-dasgupta?CMP=twt_gu

Drengson, A. \& Inoue, Y. (1995), The Deep Ecology Movement: An Introductory Anthology. Berkeley: North Atlantic Publishers.

Europar KomisioA (2016), «Regional Policy». URL: http://ec.europa.eu/regional_policy/ en/information/maps/regional_competitiveness/\#1

EUROSTAT (2016), URL: http://ec.europa.eu/eurostat/data/database

Eusko JaURlaritza (2016), Euskadiko Energia Estrategia 2030. URL: http://www. euskadi.eus/contenidos/informacion/estrategia_energetica_euskadi/eu_def/ adjuntos/3E2030_Euskadiko_Energia_Estrategia_v3.0.pdf

Eustat (2016), «I+Gko gastua (BPGaren \%) herrialdearen arabera». URL: http:// eu.eustat.eus/elementos/ele0003200/IGko_gastua_BPGdaren__herrialdearen_ arabera/tbl0003292_e.html

García, X., Domínguez, J., Linares, J. \& López, O. (2005), «Renovables 2050: Un informe sobre el potencial de las energías renovables en la España peninsular». Greenpeace. URL: http://www.greenpeace.org/espana/Global/espana/report/other/ renovables-2050.pdf

GiRARDEt, H. \& MENDONCA, M. (2009). A renewable world: energy, ecology and equality. A report for the World Future Council. Cambridge: Green Books \& Resurgence Books.

GoldthaU, A. (2017), «The G20 must govern the shift to low-carbon energy». Nature 546: $203-205$.

Havrelock, R. (2016), «Pipelines in the Sand: The Middle East After Sykes-Picot». Foreign Affairs. URL: https://www.foreignaffairs.com/articles/middle-east/2016-05-17/ pipelines-sand

Homer-Dixon, T. (2007), The Upside of Down; Catastrophe, Creativity and the Renewal of Civilisation. Washington: Island Press.

Jacobsson, S., Bergek, A., Finon, D., Lauber, V., Mitchell, C., Toke, D. \& Verbruggen, A. (2009), «EU renewable energy support policy: Faith or facts?». Energy policy 37 (6): 2143-2146.

Jacobson, M. Z., Delucchi, M. A., Bauer, Z. A., Goodman, S. C., Chapman, W. E., CamERON, M. A., ... \& ERwin, J. R. (2017). «100\% clean and renewable wind, water, and sunlight all-sector energy roadmaps for 139 countries of the world». Joule, 1(1): 108-121.

JuRADO, N. (2010), Independencia: de reivindicación histórica a necesidad económica. Iruñea: Txalaparta.

Klare, M.T. (2012), «6 Global Conflicts that have flared up over oil and gas». Alternet. URL: http://www.alternet.org/story/155372/6_global_conflicts_that_have_flared_ up_over_oil_and_gas

Lund, H. (2007), «Renewable energy strategies for sustainable development». Energy 32 (6): 912-919. 
Mikelarena, A. (2017), «Frantziak iragarri du 2025erako 17 erreaktore nuklear itxiko dituela». Berria, 2017-07-10. URL: http://www.berria.eus/albisteak/136745/ frantziak_17_erreaktore_nuklear_itxiko_dituela_iragarri_du_2025erako.htm

Monbiot, G. (2001), «Afghanistan, War and Oil. Counterpunch». Counterpunch 200109-23. URL: https://www.counterpunch.org/2001/10/23/afghanistan-war-and-oil/

Murphy, D. J. \& HALL, C. A. (2010), «Year in review-EROI or energy return on (energy) invested». Annals of the New York Academy of Sciences 1185 (1): 102-118.

Orzaiz, I. \& UnANuE, M. (2017), «Errusiako Auzitegiak Konstituzionalak Krimearen anexioa onartu du». Berria, 2014-03-19. URL: http://www.berria.eus/albisteak/ 89927/errusiako_auzitegi_konstituzionalak_krimearen_anexioa_onartu_du.htm

SAYIGH, Y. (2015), The War Over Syria's Gas Fields. Carnegie, Middle East Center. URL: http://carnegie-mec.org/diwan/60316

SMALL, M. (2006), «Privatisation of security and military functions and the demise of the modern nation-state in Africa». Accord Occasional Paper 2006 (2): 1-44.

SMIL, V. (2008), Energy in nature and society: general energetics of complex systems. Cambridge, Mass.: MIT press.

UlAZIA, A. (2016), «Energetikaren historia, oinarriak eta ondorioak zibilizazioentzat». Gogoa 14: 263-279.

Ulazia, A., Saenz, J. \& Ibarra-Berastegui, G. (2016), «Sensitivity to the use of 3DVAR data assimilation in a mesoscale model for estimating offshore wind energy potential. A case study of the Iberian northern coastline». Applied Energy 180: 617627. 